\title{
Development and implementation of a collective agreement on the example of the Tyumen transport and construction company
}

\author{
A.V. Kopytova ${ }^{1 *}, A . V$. Sumachev ${ }^{2}$, and $V$. A. Zhabskiy $^{3}$ \\ ${ }^{1}$ Tyumen Industrial University, Volodarskogo str., 38, Tyumen, 625000, Russia \\ ${ }^{2}$ Ugra State University, Chekhov str., 16, Khanty-Mansiysk, 628012, Russia \\ ${ }^{3}$ Moscow University of the Ministry of Internal Affairs of the Russian Federation named after V.Y. \\ Kikot, Academician Volgin str., 12, Moscow, 117437, Russia
}

\begin{abstract}
The legal regulation of labor relations is carried out by the state on the basis of legislative norms. Legislative norms are the minimum level, and collective agreements of the organization are interested in raising this level. Both employers and employees are interested in the development of the regulatory system. The article presents the recommended structure of the collective agreement for the Tyumen transport and construction company that carries out its activities on the territory of the Russian Federation. Also, the authors developed an algorithm for introducing this collective agreement into practice.
\end{abstract}

\section{Introduction}

The legal regulation of labor relations is carried out by the state on the basis of legislative norms, which are the minimum level. Their increase is the goal of collective bargaining. Both employers and workers are interested in the development of this system, since it performs the important functions presented in Table 1.

The modern collective agreement increasingly acquires the features of a local legal normative act designed to collectively and contractually regulate labor relations between employees and an employer in a particular company.

Table 1. Collective agreement functions

\begin{tabular}{|c|l|l|}
\hline No & \multicolumn{1}{|c|}{$\begin{array}{c}\text { Function } \\
\text { name }\end{array}$} & \multicolumn{1}{c|}{ Function characteristics } \\
\hline & $\begin{array}{l}\text { Protection of } \\
\text { the interests } \\
\text { of the social } \\
\text { and labor } \\
\text { relations } \\
\text { parties }\end{array}$ & $\begin{array}{l}\text { The protective function means that the collective agreement is designed to } \\
\text { protect employers from unreasonable demands of workers whose satisfaction } \\
\text { can disrupt the production process and cause economic damage to the } \\
\text { organization, as well as the collective agreement protects the interests of } \\
\text { employees who are a more vulnerable subject of social and labor relations, } \\
\text { from arbitrariness of unscrupulous employers. }\end{array}$ \\
\hline
\end{tabular}

*Corresponding author: a.copytowa@yandex.ru 


\begin{tabular}{|c|l|l|}
\hline No & \multicolumn{1}{|c|}{$\begin{array}{c}\text { Function } \\
\text { name }\end{array}$} & \begin{tabular}{l} 
Function characteristics \\
\hline 2
\end{tabular} \\
\hline $\begin{array}{l}\text { Organization } \\
\text { of social and } \\
\text { labor } \\
\text { relations }\end{array}$ & $\begin{array}{l}\text { The organizational function of collective-contractual relations is aimed at } \\
\text { ensuring the interest of both sides of these relations. The working conditions } \\
\text { fixed in the agreement (the amount of wages, the terms of payment, the } \\
\text { duration of the holidays, additional social benefits, etc.) allow the employer to } \\
\text { plan in advance the production costs and the expected profit. For a worker, the } \\
\text { pre-established working conditions represent certain guarantees for meeting } \\
\text { his needs and needs of his family. }\end{array}$ \\
\hline 3 & $\begin{array}{l}\text { Ensuring the } \\
\text { stability of } \\
\text { social and } \\
\text { labor } \\
\text { relations }\end{array}$ & $\begin{array}{l}\text { The stabilization function presupposes the establishment of procedures for } \\
\text { coordinating requirements, addressing the problems of both parties and } \\
\text { creating guarantees of social and economic stability ensured by the prohibition } \\
\text { of strikes during the term of the collective agreement. }\end{array}$ \\
\hline
\end{tabular}

\section{Methods}

Collective agreement is higher on the legal force than local normative legal acts, because if the collective agreement and local normative legal acts had equal legal force, then after the entry into force of the local regulatory legal act worsening the situation of employees in comparison with the collective agreement, the provisions of this local regulatory legal act in accordance with Art. 12 of the Labor code of the Russian Federation.

In the process of developing a collective agreement, the company identifies seven main stages: preparatory, analytical, structural, project, editorial, discussions, approval of the collective agreement (Table 2).

Table 2. Stages of development of the collective agreement

\begin{tabular}{|c|c|}
\hline Stage & Contents of the stage \\
\hline Preparatory & The parties of the agreement determine the working group \\
\hline analytical & $\begin{array}{l}\text { Analysis of labor contracts, terms of payment, job descriptions } \\
\text { Study of external factors } \\
\text { Calculation of indicators that characterize the social conditions of the enterprise }\end{array}$ \\
\hline structural & $\begin{array}{l}\text { Development of the structure of the collective agreement } \\
\text { Clarification of the structure of the collective agreement }\end{array}$ \\
\hline project & $\begin{array}{l}\text { Development of sections of the collective agreement } \\
\text { Harmonization of the sections of the collective agreement with employees } \\
\text { Clarifying the content of the sections as a result of harmonization }\end{array}$ \\
\hline editorial & Editing the text of the collective agreement project \\
\hline discussions & $\begin{array}{l}\text { Discussion of the collective agreement project in structural divisions of the } \\
\text { organization } \\
\text { Consideration of comments and proposals to the collective agreement project }\end{array}$ \\
\hline approval & $\begin{array}{l}\text { Approval of the final version of the collective agreement } \\
\text { Signature by the parties }\end{array}$ \\
\hline
\end{tabular}

The content and structure of the collective agreement is determined by the parties. The collective agreement may include the obligations of the employer and employees on the following issues:

- Forms, systems and amount of remuneration;

- Payment of benefits, compensations;

- Employment, retraining, conditions for the release of workers;

- Working hours and rest time, including questions of granting and duration of holidays; 
- Conditions and labor protection;

- Guarantees and benefits to employees;

- Refusal to strike when the relevant conditions of the collective agreement are fulfilled;

- Other matters as determined by the parties.

The decision on the need to conclude a collective agreement with the employer may be taken by representatives of employees or the general meeting of employees of the organization.

The collective agreement is concluded for a period of one to three years and comes into effect from the moment it is signed by the parties or from the date fixed in the contract. Parties can extend it for a period not exceeding three years. At the end of the term, it continues to operate until the conclusion of a new agreement or amendment, supplementing the parties in force. The collective agreement retains its effect in the event of a change in the composition, structure, name, management body of an organization, the dismissal of its leader.

\section{Results}

The company "ALEX-Group" is producting complex works in the field of industrial and civil construction.

The company renders services in the field of new design, inspection of industrial and civil buildings and structures, technical testing of building structures, develops projects for reconstruction, repair of buildings and structures, develops technical solutions for strengthening structures and foundations. Also the main direction of the company is the development of solutions for waterproofing, dewatering and drainage systems.

The geography of the works of LLC "ALEX-Group" stretches from the peninsula Crimea to the Kuril Islands. ALEX-Group conducts scientific research in the field of foundations. At the present time, the main direction of scientific research of the company is the strengthening of weak bases by geosynthetic materials and injection methods.

Currently, all employees are employed under temporary (urgent) contracts. It is practiced to conclude contracts for the execution of incoming orders. The company's personnel has a significant impact on revenue, and as a result, profits and businesses. The calculation of the two-factor model of revenue dependency on the number and productivity of the employees of ALEX-Group LLC showed that in 2016 the change in sales proceeds (in a positive direction - growth) was due to: an increase in the number of employees by more than 0.8 million. rub. and due to changes in labor productivity, an increase of almost 0.4 million rubles. In 2017, revenue from sales due to changes in the number of employees increased by 0.92 million rubles, due to changes in labor productivity, growth was almost 1.3 million rubles. The gross income from the sale of works and services is increasing annually.

The company is developing and the strategic vision of the development of the situation and the withdrawal of managerial processes to a new level becomes especially topical for management. Important blocks are the timely establishment of all processes, which is impossible without the creation of an actual viable framework of regulatory documents.

The regulations of the company include: the charter, regulations on the division, job descriptions, schemes of organizational management structures; rules of internal labor regulations; different norms of time, numbers, controllability, etc..

The audit of regulatory documents on personnel showed that in ALEX-Group LLC there were developed: job descriptions, internal labor regulations, labor contracts and a provision on labor remuneration. It should be noted that the list of documents is meager. This is due to the fact that regulatory issues in the organization are currently being 
considered superficially. The head of the company notes that the development of regulatory documents gradually, with the development of various areas of work of LLC "ALEXGroup", is beginning to acquire significance. However, these problems do not go to the top of the agenda due to the fact that in general the work is carried out in some way, it is always possible to resolve any issue through negotiations in the process of arising relationships between the participants. Also, the head of LLC "ALEX-Group", during the conversation, noted that he considers it not permissible to create bureaucratic barriers. And this is possible with a large number of regulatory documents. He admits the introduction of any regulations, but there should not be a significant amount, since in the opposite case it will become formal again.

LLC "ALEX-Group" covers its activities throughout Russia from the Crimea to the Kuril Islands. The company has doubled its financial results in three years. The head of the enterprise thinks strategically and is aimed at the further development of the company. This necessarily implies the expansion of staff, the growth in the number of facilities and customers. Thus, as a preventive measure, it is now important to understand the need to regulate the activities of employees.

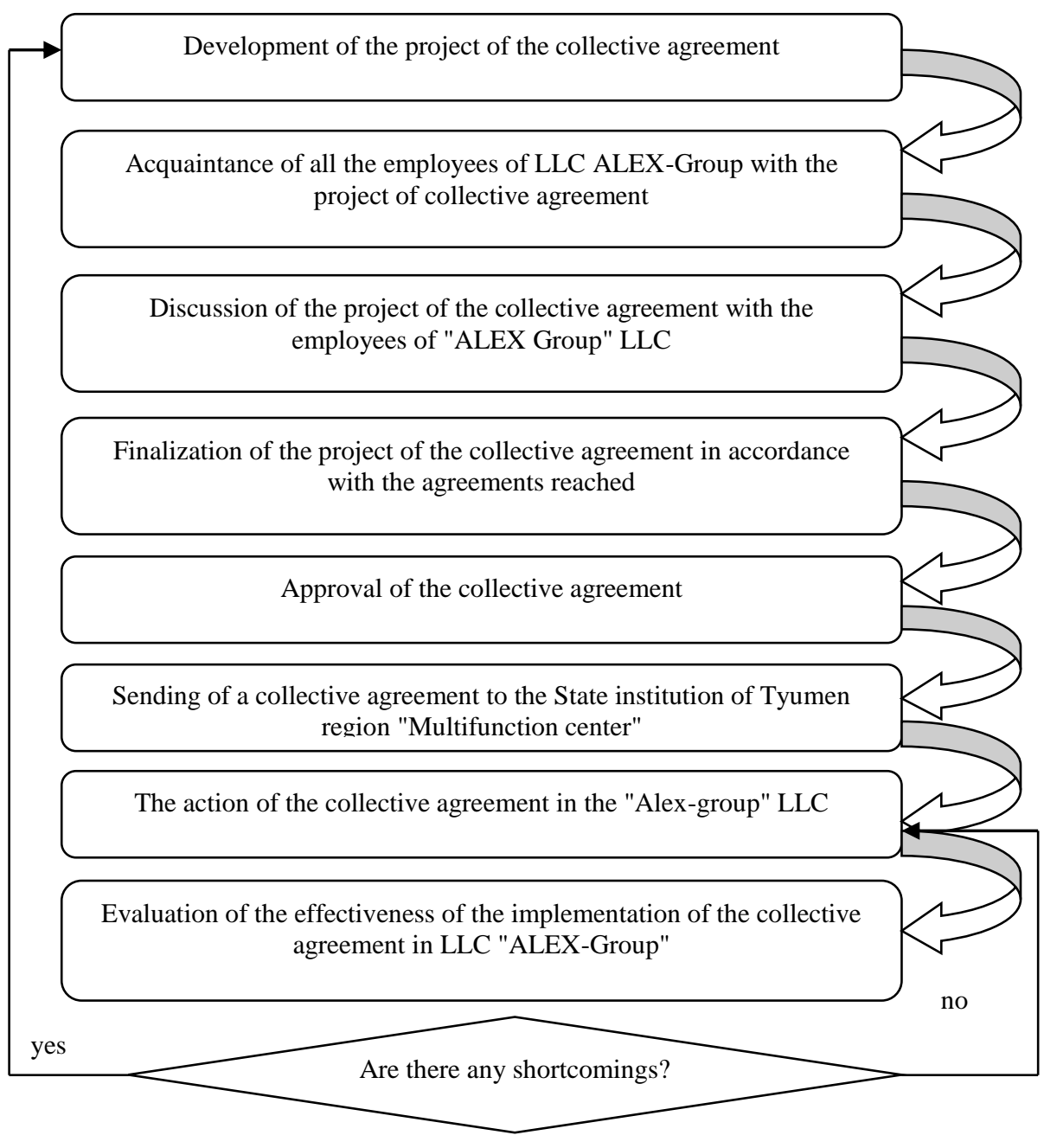

Fig. 1. Situational scheme of territory 
As a key normative-applied tool, it is proposed to consider the process of development and implementation of the collective agreement by the LLC "ALEX-Group".

The structure of the proposed collective agreement of the LLC "ALEX-Group" represents the following sections:

1. General Provisions

2. Employment contract. Providing employment. Retraining. Conditions for the release of workers;

3. Working hours;

4. Rest time;

5. Remuneration;

6. Working conditions. Labor protection and safety;

7.Payment of benefits and compensation. Employee guarantees;

8. Social welfare of employees;

9. Final Provisions.

Figure 1 presents the recommended algorithm for implementing the project of the collective agreement.

Thus, the introduction of regulations into the activities of the company only in that case will bring the expected positive effect if this issue is treated with all seriousness from the very beginning, taking into account all possible difficulties and nuances, as well as ensuring proper control over regulation at all stages of its development in the company.

\section{Discussion}

The conclusion of a collective agreement is voluntary. Articles 21 and 22 of the LC RF provide for the right, and not the obligation of the employee and employer to conclude a collective agreement. In addition, no one can force an employee to join a contract already concluded (Article 21 of the Labor Code does not require the employee to join a collective agreement).

However, the collective agreement proposed by ALEX-Group LLC is developed and supplemented from the professional point of view and takes into account the interests of both management and employees. Table 3 shows the expected effect of the implementation of the collective agreement in the system of labor regulations of the personnel of this organization.

Table 3. The expected effect of the implementation of the collective agreement in the system of labor regulations of the personnel of LLC "ALEX-Group"

\begin{tabular}{|l|l|l|}
\hline Description of the event & Expenses & Result from implementation \\
\hline $\begin{array}{l}\text { 1. Preservation of the employment level } \\
\text { in LLC ALEX-Group at least 90\% of } \\
\text { the existing at the time of the } \\
\text { conclusion of the agreement }\end{array}$ & No & $\begin{array}{l}\text { Workers will work with full } \\
\text { dedication, maintaining } \\
\text { commitment to the enterprise }\end{array}$ \\
\hline $\begin{array}{l}\text { 2. Provision by the employer of the re- } \\
\text { qualification of employees within the } \\
\text { framework of ALEX-Group LLC with } \\
\text { the reduction of workplaces for } \\
\text { available vacant positions }\end{array}$ & No & $\begin{array}{l}\text { The enterprise receives workers } \\
\text { already familiar with the specifics } \\
\text { of the production process, with } \\
\text { the organizational culture, with } \\
\text { the management policy, there are } \\
\text { no downtime due to training of } \\
\text { employees }\end{array}$ \\
\hline $\begin{array}{l}\text { 3. Maintenance of the preemptive right } \\
\text { to return to the enterprise of the reduced } \\
\text { employee }\end{array}$ & No & $\begin{array}{l}\text { Providing workers with timely } \\
\text { payment of wages }\end{array}$ \\
\hline $\begin{array}{l}\text { 4. Payment by the employer of } \\
\text { compensation for delay of wages }\end{array}$ & No & \\
\hline
\end{tabular}




\begin{tabular}{|c|c|c|}
\hline $\begin{array}{l}\text { 5. Appointment of employees who } \\
\text { reached retirement age and laid off due } \\
\text { to retirement, a one-time payment of } 3 \\
\text { thousand rubles. }\end{array}$ & $\begin{array}{l}\text { The maximum } \\
\text { costs of } 4.73 \\
\text { thousand rubles. } \\
\text { LLC "ALEX- } \\
\text { Group" does not } \\
\text { plan to appear } \\
\text { in } 2019-2021 . \\
\text { workers of pre- } \\
\text { retirement age, } \\
\text { the probability } \\
\text { of paying these } \\
\text { costs is low }\end{array}$ & $\begin{array}{l}\text { The possibility of hiring young } \\
\text { professionals with higher labor } \\
\text { productivity; reduction of the } \\
\text { unemployment rate in the region, } \\
\text { a reduction in the cost of paying } \\
\text { hospital cards to pensioners }\end{array}$ \\
\hline $\begin{array}{l}\text { 5. Provision of additional leave to } \\
\text { workers engaged in work with } \\
\text { hazardous working conditions and an } \\
\text { unregulated working day }\end{array}$ & $\begin{array}{l}\text { Maximum Costs } \\
84.28 \text { thousand } \\
\text { rubles. }\end{array}$ & $\begin{array}{l}\text { Decrease in turnover of staff, } \\
\text { reduction of expenses for } \\
\text { payment of sick leaves and } \\
\text { treatment }\end{array}$ \\
\hline TOTAL: & \multicolumn{2}{|c|}{89.01 thousand rubles. } \\
\hline
\end{tabular}

Guaranteeing employees a fixed level of employment, the company will have a positive effect, as employees, being confident of their future, will work with full dedication, maintaining the commitment to ALEX Group LLC, which provides them with such guarantees.

\section{Conclusion}

The above-mentioned construction company has doubled its financial results in three years. The head of the enterprise thinks strategically and is aimed at the further development of the organization. This necessarily implies the expansion of staff, the growth in the number of facilities and customers. Thus, as a preventive measure, it is now important to understand the need to regulate the activities of employees.

In the article the authors proposed the structure of the collective agreement of LLC "ALEX-Group" and an algorithm for the introduction of this document into activities.

The setting of any management subsystem in the company requires the presence of an appropriate regulatory document that determines how this subsystem should function. An important condition for the effective operation of the company is not only the existence of regulations, but also their clear implementation.

To introduce regulations means to ensure that the system allows to achieve all the goals for which it was implemented. Argument against the regulation of the company's activities lead to considerable instability of the external environment. But in modern conditions, companies that do not have the proper level of organizational and financial discipline simply can not stand the tough competition. The introduction of clear regulations will allow for a certain period to identify the majority of shortcomings and reserves to improve the efficiency of the company.

\section{References}

1. N. Zotkina, M. Gusarova, A. Kopytova, Advances in Intelligent Systems and Computing 692, 1204-1213 (2018) DOI: 10.1007/978-3-319-70987-1_129
2. A. Kopytova, Procedia
Engineering
165, 1132
(2016)
DOI: 10.1016/j.proeng.2016.11.830 
3. A. Kopytova, MATEC Web of Conferences, 106, 08056 (2017) DOI: 10.1051/matecconf/201710608056

4. N. Zotkina, S. Bardasov, M. Gusarova, A. Kopytova, MATEC Web of Conferences, 106, 08050 (2017) DOI: 10.1051/matecconf/201710608050

5. K. Pykhtin, T. Simankina, V. Sharmanov, A. Kopytova, IOP Conference Series: Earth and Environmental Science, 90 (1), 012065 (2017) DOI: 10.1088/1755$1315 / 90 / 1 / 012065$

6. V. Lezier, M. Gusarova, A. Kopytova, IOP Conference Series: Earth and Environmental Science, 90 (1), 012034 (2017) DOI: 10.1088/1755-1315/90/1/012034

7. A. Minnullina, R. Abdrazakov, Advances in Intelligent Systems and Computing 692, 1224-1233 (2018) DOI: 10.1007/978-3-319-70987-1_131

8. A.V. Kopytova, Exchange of intellectual property 3 (XIV), 31-37 (2015)

9. V. Lezier, M. Gusarova, A. Kopytova, IOP Conference Series: Earth and Environmental Science, 90 (1), 012069 (2017) DOI: 10.1088/1755-1315/90/1/012069

10. A. Mottaeva, A. Minnullina, IOP Conference Series: Earth and Environmental Science, 90 (1), 012123 (2017) DOI: 10.1088/1755-1315/90/1/012123

11. M. Gravit, O. Zybina, A. Vaititckii, A. Kopytova, IOP Conference Series: Earth and Environmental Science, 90 (1), 012103 (2017) DOI: 10.1088/1755-1315/90/1/012103

12. N. Zotkina, A. Kopytova, M. Zenkina, O. Zhigunova, MATEC Web of Conferences, 106, 08058 (2017) DOI: 10.1051/matecconf/201710608058

13. Fedorov, M., Matys, E., Kopytova, A. E3S Web of Conferences, 33, 03054 (2018) DOI: $10.1051 / \mathrm{e} 3$ sconf/20183303054 